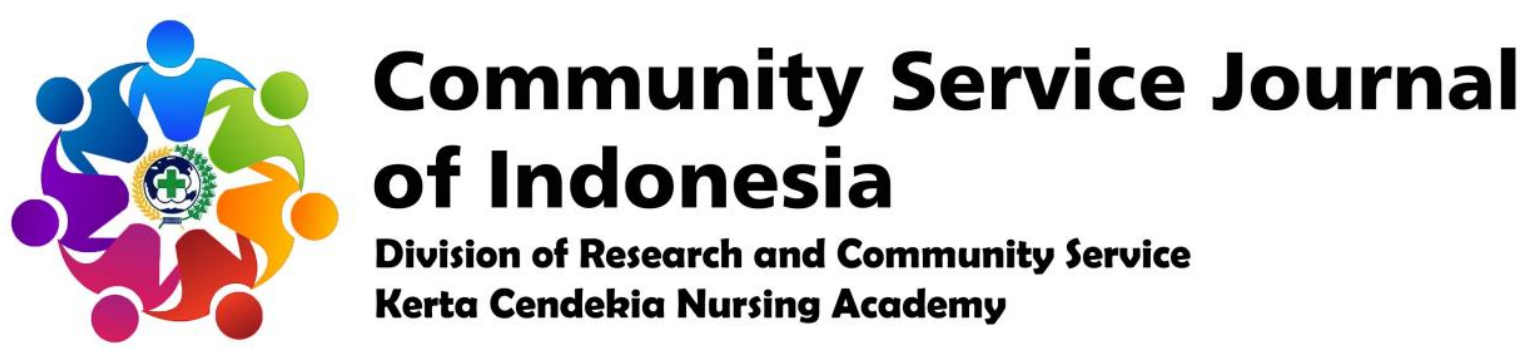

https://ejournal-kertacendekia.id/index.php/csji/index

Community Service Journal of Indonesia 1 (1) (2019): 4-7

DOI: https://doi.org/10.36720/csji.v1i1.65

\title{
HEALTHY LIFE AWARENESS IMPROVEMENT THROUGH HANDWASH HEALTH PROMOTION IN THE KEBONSARI ELEMENTARY SCHOOL, CANDI SUB-DISTRICT, SIDOARJO DISTRICT, EAST JAVA PROVINCE
}

\author{
Faida Annisa $^{1}$, Muhebbi ${ }^{2}$, Ria Devi², Chyntia Tanzila², Bagus Eka Windarta ${ }^{2}$, Nor \\ Aslina $^{2}$, Nora Aditya ${ }^{2}$, Nadia Putri ${ }^{2}$ \\ ${ }^{1}$ Lecturer of Kerta Cendekia Nursing Academy, Sidoarjo \\ ${ }^{2}$ Student of Kerta Cendekia Nursing Academy, Sidoarjo
}

\begin{abstract}
An increase in awareness of healthy living through health promotion in the Kebonsari Elementary School, Candi Sub-District, Sidoarjo District, East Java Province is a form of education in the form of counseling aimed at fostering and improving healthy behavior in children early, especially in carrying out clean and healthy behaviors (PHBS) with 6-step hand washing. The activity was held on December 12, 2017 at Kebonsari Elementary School, Kebonsari Village, Candi District, Sidoarjo Regency, East Java Province. With the aim is fourth grade students at Kebonsari Elementary School, Kebonsari Village, Candi Sub-District, Sidoarjo District, East Java Province. Before the implementation of the activity, there is a process of preparing activities for 3 weeks before the activities are carried out, starting from the selection of health counseling materials to the submission of permits to related parties. As an evaluation, the activity was attended by 52 female students and 1 teacher, participants participated in the activity enthusiastically and conductively, the activities could be carried out on time smoothly.
\end{abstract}

Keywords: Handwash health promotion, healthy life awareness, elementary school, 6-step hand washing.

\section{INTRODUCTION}

Hand washing is the most important basic technique in preventing and controlling infection (Potter \& Perry,
2005). Hand washing is the process of removing dirt and dust mechanically from both hands using soap and water. The purpose of hand washing is to remove dirt 
and dust mechanically from the surface of the skin and reduce the number of microorganisms (Tietjen, 2003). Diarrhea is usually transmitted from unhygienic hands. Germs then expose to the person who ate them. This can be prevented by always washing hands after using the toilet and before preparing food (Darmiatun, 2013). Washing your hands can also eliminate a large number of viruses that cause various diseases, especially diseases that attack the gastrointestinal tract such as diarrhea, and channel breathing such as influenza. Almost everyone understands the importance of hand washing with soap, but many still do not get used to doing right at important times. Some people know the importance of hand washing, but in reality, there are still very few, only 5\% know how to do it right. This is very important to be taught to the community so that the bias can prevent the occurrence of disease (Siswanto, 2009).

According to WHO research, 100 thousand of Indonesians die every year from diarrhea. Data released by Riskedas in 2007 stated that diarrhea was one of the two biggest causes of death in children, in addition to pneumonia. Death in children aged 4-11 years due to diarrhea was $25.5 \%$ and pneumonia was $15.5 \%$. As many as $40-$ $60 \&$ diarrhea in children occur due to rotavirus. Usually the virus enters the mouth through contaminated hands due to not washing hands.

These problems arise because of lack of knowledge and awareness of the importance of health, especially hand washing habits. Hand washing is an easy and effective way to prevent infectious diseases. But until now these habits are often underestimated (Sari, 2011). Based on WHO handwashing studies using soap can reduce the incidence of diarrhea by
47\% (Darmiatun, 2008). Washing hands with soap reduces respiratory tract infections associated with pneumonia by more than $50 \%$.

By providing counseling about hand washing, it is expected that the infectious disease can reduce the risk of disease transmission through hands by washing hands. Foods and drinks that enter with dirty hands can transmit the disease, try washing hands with running water and soap when preparing and eating food and after defecation.

\section{OBJECTIVES}

General Purpose

1. After health promotion, elementary school students are expected to understand and understand about 6-step hand washing.

2. After health promotion, students are able to practice 6-step hand washing.

\section{Special Purpose}

After taking health promotion measures, it is expected that the $4^{\text {th }}$ grade students of Kebonsari Elementary School, Kebonsari Village, Candi Sub-District, Sidoarjo District, East Java Province can:

1. Explain the definition of hand washing.

2. Explain the purpose of washing hands.

3. Explain the benefits of hand washing.

4. Explain the impact if you don't wash your hands.

5. Explain when to wash hands.

6. Explain the six steps of hand washing.

\section{PLAN OF ACTION}

Strategy Plan

The strategy plan implemented, including:

1. Coordinate with the principal of Kebonsari Elementary School, Kebonsari Village, Candi Sub-District, 
Sidoarjo District, East Java Province to apply for permission to carry out health education or counseling as an activity of the nursing program and to help provide guidance to the $4^{\text {th }}$ students of Kebonsari Elementary School, Kebonsari Village, Candi Sub-District, Sidoarjo District, East Java Province.

2. Establish students in the implementation of health education or counseling to know about healthy life awareness through 6-step hand washing.

3. Contract time with the $4^{\text {th }}$ students of Kebonsari Elementary School, Kebonsari Village, Candi Sub-District, Sidoarjo District, East Java Province.

4. Provide health promotion about 6-step hand washing.

\section{Implementation}

Actions taken in the implementation of these activities, including:

1. Contacted the principal of Kebonsari Elementary School, Kebonsari Village, Candi Sub-District, Sidoarjo District, East Java Province to request permission for activities and gather the $4^{\text {th }}$ students of Kebonsari Elementary School, Kebonsari Village, Candi SubDistrict, Sidoarjo District, East Java Province.

2. Prepare a place and counseling media.

3. the $4^{\text {th }}$ students of Kebonsari Elementary School, Kebonsari Village, Candi Sub-District, Sidoarjo District, East Java Province received extension materials.

\section{Setting}

This activity was carried out at Kebonsari Elementary School, Kebonsari Village, Candi Sub-District, Sidoarjo District, East Java Province.
Target

Target in this activity is all of the $4^{\text {th }}$ grade students at Kebonsari Elementary School, Kebonsari Village, Candi SubDistrict, Sidoarjo District, East Java Province.

\section{RESULTS AND DISCUSSION}

Activities start at 08.30-09.00 WIB in class IV $\mathrm{B}$ and continue in class IV $\mathrm{A}$ at 09.00-09.30 WIB. Health promotion activities are carried out by conveying the meaning of handwashing, the purpose of washing hands, when to wash hands, the impact of not washing hands, how to wash hands properly.

Health promotion lasts 60 minutes. 30 minutes in class IV $\mathrm{A}$ and 30 minutes in class IV B with questions and answers. Health promotion is closed which begins with evaluation and conclusions.

Participants ask questions they don't know yet. Active participation from the students of the Kebonsari Elementary School by practicing 6 steps of hand washing. Participants attended 24 students from class IV A and 28 students from class IV B.

Based on the results of the evaluation conducted illustrate that the success of health promotion about hand washing 6 Steps is as much as $80 \%$ of participants were able to apply the 6-step hand washing.

\section{CONCLUSION}

Healthy life awareness improvement through handwash health promotion in the Kebonsari Elementary School, Candi SubDistrict, Sidoarjo District, East Java Province was considered quite successful because almost all students were able to apply the 6-step hand washing as much as $80 \%$ of participants. 


\section{REFERENCES}

Darmiatun, S. (2008). Improvement strategy to quality management system in teaching of workshop activity at vedc malang through implementation of environment management system. SEAVERN Journals, 1(1).

Darmiatun, S. (2013). Menyusun Modul Bahan Ajar Untuk Persiapan Guru Dalam Mengajar. Yogyakarta: Gava Media.

Potter, P., \& Perry, A. G. (2005). Fundamental Keperawatan, Konsep, Proses dan Praktik. Jakarta: EGC.

Siswanto, H. (2009). Informal health education for early childhood in Indonesia. EDUCARE, 1(2).

Sari, D. A. (2011). Pengaruh pendidikan kesehatan perilaku hidup bersih sehat tentang cuci tangan terhadap tingkat pengetahuan dan keterampilan pada anak usia sekolah sdn tlogo imbas gugus 3, tamantirto kasihan bantul. FKIK

(Ilmu Keperawatan), 7(7).

Tietjen, K. (2003). The Bangladesh primary education stipend project: a descriptive analysis. Partnership on Sustainable Strategies for Girls' Education.

Brunner \& Suddarth. (2002). Keperawatan Medikal Bedah. Jakarta: EGC.

JNPK KR. (2004). Panduan pencegahan infeksi untuk fasilitas pelayanan kesehatan dengan sumber daya terbatas. Jakarta: Yayasan Bina Pustaka Sarwono Prawiroharjo.

Suproharta, M., Wahyu, J.K. Wlewik, S. (2000). Kapita selekta kedokteran, ED: 3 jilid: 1. Jakarta: Media Aesculapius FKUI.

Tarwoto, W. (2006). Kebutuhan dasar manusia dan proses keperawatan. Jakarta: Salemba Medika. 